ANALISIS PERBEDAAN DIVIDEN PADA PERUSAHAAN

KELUARGA DAN NON KELUARGA BERDASARKAN

KEPEMILIKAN ULTIMAT

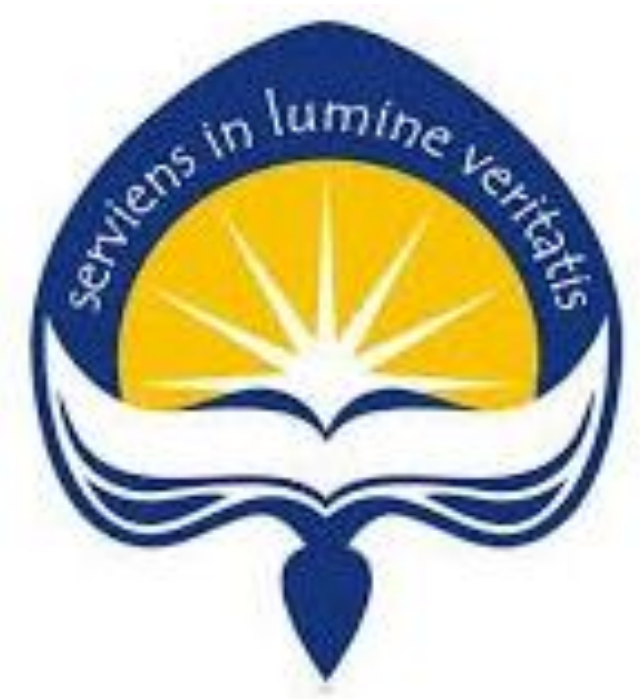

Krisnati Adi Cahyani

I Putu Sugiartha Sanjaya

AKUNTANSI

FAKULTAS EKONOMI

UNIVERSITAS ATMA JAYA YOGYAKARTA

JALAN BABARSARI 43-44, YOGYAKARTA 


\title{
ANALISIS PERBEDAAN DIVIDEN PADA PERUSAHAAN \\ KELUARGA DAN NON KELUARGA BERDASARKAN \\ KEPEMILIKAN ULTIMAT
}

\author{
Disusun oleh: \\ Krisnati Adi Cahyani \\ NPM: 100418548
}

\section{Pembimbing}

Dr. I Putu Sugiartha Sanjaya, SE., M.Si., CA., Ak.

\begin{abstract}
Abstrak
Penelitian ini bertujuan untuk menganalisis apakah terdapat perbedaan pembagian dividen pada perusahaan keluarga dan non keluarga berdasarkan kepemilikan ultimat. Sampel yang digunakan dalam penelitian ini adalah sebanyak 400 perusahaan manufaktur yang terdaftar di BEI, dengan periode penelitian 2009-2012. Pengambilan sampel menggunakan metode purposive sampling. Data yang digunakan merupakan data sekunder yang diperoleh dari web BEI dan Data mengenai struktur kepemilikan diperoleh dari Pusat Data Bisnis Indonesia melalui penelitian Sanjaya (2010).

Hasil penelitian yang dilakukan menunjukkan bahwa terdapat perbedaan pembagian dividen antara perusahaan keluarga dan non keluarga. Perusahaan keluarga membagikan dividen yang lebih rendah dibanding perusahaan non keluarga.
\end{abstract}

Kata kunci : Dividen, Teori Keagenan, Kepemilikan Keluarga 


\section{PENDAHULUAN}

\section{Latar Belakang Masalah}

Struktur kepemilikan dapat menyebabkan masalah keagenan yaitu tidak selarasnya tindakan yang dilakukan manajer (agen) dengan kepentingan pemegang saham (prinsipal). Pada struktur kepemilikan yang tersebar, saham perusahaan mayoritas dimiliki oleh banyak orang yang sebagian besar adalah masyarakat umum. Manajemen bertugas untuk menjalankan kegiatan perusahaan sehingga mendatangkan profit yang menguntungkan pemegang saham. Masalah keagenan terjadi ketika manajer memiliki kepentingan yang sudah tidak selaras lagi dengan pemegang saham. Manajer akan melakukan tindakan yang hanya menguntungkan pihaknya saja sehingga merugikan pemegang saham. Masalah keagenan seperti ini disebut masalah keagenan tipe 1. Sementara masalah keagenan tipe 2 yaitu masalah keagenan yang terjadi antara pemegang saham mayoritas (pemegang saham pengendali) dan pemegang saham minoritas (pemegang saham non pengendali). Masalah ini terjadi pada struktur kepemilikan yang terkonsentrasi. Masalah keagenan muncul ketika pemegang saham pengendali berusaha mendapatkan manfaat privat yang tidak menguntungkan pemegang saham non pengendali.

Perusahaan di Indonesia memiliki struktur kepemilikan yang cenderung terkonsentrasi. Fakta ini mengacu pada penelitian yang dilakukan oleh La Porta et al. (1999) tentang struktur kepemilikan 691 perusahaan publik yang ada di 27 negara dengan menggunakan konsep kepemilikan ultimat. Konsep kepemilikan ultimat dapat mengidentifikasi struktur kepemilikan hingga rantai kepemilikan paling akhir. La Porta et al. (1999) menemukan bahwa perusahaan publik di Asia Tenggara dikendalikan oleh pemegang saham ultimat. Hasil ini juga didukung oleh penelitian yang dilakukan oleh Claessens et al. (2002) mengenai struktur kepemilikan perusahaan di sembilan negara Asia menunjukkan bahwa perusahan-perusahaan publik di Asia mempunyai struktur kepemilikan yang terkonsentrasi. Sebanyak 54\% perusahaan publik khusunya di Asia dikendalikan oleh pihak keluarga (Claessens et al., 2000). Perusahaan keluarga adalah perusahaan yang dijalankan oleh penerus dari orang yang sebelumnya bertanggungjawab terhadap perusahaan atau oleh keluarga yang dalam proses untuk menyerahkan kendali perusahaan kepada penerusnya (Morck dan Yeung, 2004). Walau begitu, tidak semua pekerja berasal dari keluarga tapi juga berasal dari luar keluarga. Namun, biasanya keluarga selalu menempati posisi puncak dalam perusahaan. Perusahaan keluarga yang ada di Indonesia seperti PT Bakrie \& Brothers Tbk, PT Indofood Sukses Makmur Tbk, Salim Group, Sinar Mas, Martha Tilaar Group dan lain-lain.

Sebagai perusahaan keluarga, kesejahteraan keluarga merupakan sebuah prioritas. Oleh karena itu, perusahaan keluarga biasanya memiliki rencana jangka panjang agar perusahaan terus bertumbuh sehingga kesejahteraan keluarga akan terjamin. Perusahaan keluarga cenderung melibatkan anggota keluarganya dalam manajemen perusahaan. Orang-orang yang ditempatkan untuk masuk ke jajaran manajemen biasanya memiliki loyalitas dan berdedikasi tinggi karena bekerja di perusahaan sendiri. Pengambilan keputusan dalam perusahaan keluarga dapat dikatakan cukup fleksibel karena mayoritas pihak manajer berasal dari keluarga sehingga birokrasi perusahaan 
tidak terlalu rumit. Meskipun begitu, perusahaan keluarga tidak lantas terbebas dari benturan kepentingan. Kepentingan tersebut seperti mempekerjakan dan mempertahankan anggota keluarga yang tidak memiliki kompetensi di bidangnya. Penempatan posisi bukan berdasarkan kompetensi yang dimiliki tetapi berdasarkan keinginan seorang anggota keluarga yang ingin menempati posisi itu. Padahal kompetensi merupakan hal yang penting dalam menduduki sebuah posisi di suatu perusahaan karena menjadi penentu akan menjadi apa perusahaan kedepannya. Perusahaan keluarga masih enggan untuk mempekerjakan orang-orang profesional diluar keluarga. Jika hal ini dipertahankan maka akan menurunkan dan membahayakan kinerja perusahaan.

Struktur kepemilikan yang terkonsentrasi menyebabkan keluarga sebagai pemegang saham pengendali berpengaruh dalam penentuan kebijakan perusahaan. Salah satu kebijakan penting dalam perusahaan yaitu kebijakan dividen. Berdasarkan penelitian Mahadwartha (2002) struktur kepemilikan saham mempengaruhi kebijakan dividen suatu perusahaan. Kebijakan dividen adalah kebijakan yang diambil oleh pihak manajemen atas laba yang dihasilkan perusahaan akan didistribusikan ke pemegang saham sebagai dividen atau ditahan guna pembiayaan investasi. Jika manajemen memilih untuk membayar dividen maka sumber pendanaan internal akan berkurang Sebaliknya jika manajemen memilih untuk tidak membayar dividen maka peluang perusahaan untuk investasi akan meningkat karena laba yang dihasilkan sepenuhnya digunakan untuk investasi sehingga pendanaan internal meningkat. Berdasarkan Undang-undang No. 40 Tahun 2007 tentang perseroan terbatas, pembagian dividen dilakukan berdasarkan keputusan Rapat Umum Pemegang Saham Tahunan (RUPST) atau Rapat Umum Pemegang Saham Luar Biasa (RUPSLB). Undang-undang nomor 40 tahun 2007 pasal 71 mengungkapakan bahwa dividen hanya bisa dibagikan apabila perseroan mempunyai saldo laba yang positif.

Keluarga memiliki suara yang cukup kuat dalam menentukan kebijakan dividen saat Rapat Umum Pemegang Saham (RUPS). Seperti yang dijelaskan di atas, bahwa konflik keagenan bukan lagi antara manajer dan pemegang saham tetapi sudah bergeser antara pemegang saham pengendali dan pemegang saham non pengendali. Keluarga sebagai pemegang saham pengendali akan mengambil keputusan sesuai keinginan keluarga sehingga rentan dengan konflik kepentingan. Apalagi jika keluarga terlibat dalam manajemen perusahaan, situasi ini semakin mendukung keluarga untuk membuat keputusan yang bisa saja hanya menguntungkan pihaknya dengan melakukan ekspropriasi. Ekspropriasi merupakan tindakan yang dilakukan pemegang saham pengendali untuk memaksimumkan kesejahteraan sendiri dengan menggunakan hak kontrol yang dimiliki (Claessens et al, 2000). Ekspropriasi tersebut dapat berupa pemberian gaji dan bonus yang berlebihan ataupun melakukan transaksi dengan pihak yang berelasi. Kebijakan dividen ibarat dua sisi mata uang dimana bisa digunakan sebagai sarana untuk mengurangi atau indikasi ekspropriasi. Oleh karena itu, dividen bisa mengurangi atau malah meningkatkan konflik keagenan antara keluarga dan pemegang saham minoritas. 
Penelitian mengenai kebijakan dividen pada perusahaan keluarga pernah dilakukan oleh Pindado et al. (2012) dengan sampel 645 perusahaan di zona Euro dimana 482 perusahaan merupakan perusahaan keluarga dan 163 perusahaan non keluarga. Hasilnya membuktikan bahwa perusahaan keluarga membagikan dividen yang lebih tinggi dan lebih stabil dibandingkan perusahaan non keluarga. Perusahaan menjadikan dividen sebagai alat untuk mengatasi masalah keagenan yang terjadi dalam struktur kepemilikan terkonsentrasi yaitu antar pemegang saham pengendali dan pemegang saham non pengendali. Pembayaran dividen melindungi pemegang saham non pengendali dari tindakan ekspropriasi yang mungkin saja dilakukan pemegang saham pengendali.

Sejalan dengan penelitian yang dilakukan Atmaja et al. (2009) yaitu perusahaan keluarga membagikan dividen lebih tinggi dibanding non keluarga pada perusahaan publik di Australia. Dengan membagikan dividen yang tinggi berarti perusahaan keluarga tidak melakukan ekspropriasi terhadap pemegang saham minoritas. Hasil yang berbeda terdapat dalam penenlitian Wei et al. (2011) yaitu perusahaan keluarga memiliki dividend payout ratio yang lebih rendah sehingga membayar dividen yang cukup kecil dibandingkan perusahaan non keluarga.

\section{Rumusan Masalah}

Rumusan masalah dalam penelitian ini adalah :

apakah terdapat perbedaan pembagian dividen antara perusahaan keluarga dan non keluarga?

\section{LANDASAN TEORI DAN PENGEMBANGAN HIPOTESIS \\ 1. Landasan Teori \\ 1.1 Teori Keagenan}

Teori keagenan merupakan dasar teori yang mendasari praktik bisnis perusahaan. Teori ini memberikan penjelasan hubungan kontrak antara prinsipal (pemilik modal) dan agen (pihak yang mengelola perusahaan) dalam bentuk kontrak kerja sama. Jensen dan Meckling (1976) menyatakan bahwa hubungan keagenan adalah sebuah kontrak antara manajer (agen) dan pemegang saham (prinsipal). Eisenhardt (1989) menyatakan bahwa teori keagenan menggunakan tiga asumsi sifat manusia yaitu: (1) manusia pada umumya mementingkan diri sendiri (self interest), (2) manusia memiliki daya pikir terbatas mengenai persepsi masa mendatang (bounded rationality), dan (3) manusia selalu menghindari risiko (risk averse). Berdasarkan asumsi tersebut hal yang paling umum terjadi adalah manusia bertindak atas kepentingan mereka. Pemegang saham hanya tertarik kepada return atas dana yang diinvestasikan di perusahaan tersebut sementara para manajer tertarik kepada kompensasi yang akan diterima jika mereka bisa memberikan return bagi pemegang saham.

Hubungan keagenan dapat menimbulkan konflik ketika terjadi perbedaan kepentingan antara pemegang saham dan manajer. Manajer akan membuat kebijakan-kebijakan yang akan menguntungkan sepihak dan mengabaikan kepentingan pemegang saham. Konflik yang terjadi antara pemegang saham dan manajer disebut konflik keagenan tipe 1. Konflik keagenan tipe 1 terjadi akibat struktur kepemilikan yang tersebar seperti yang dijelaskan Berle dan 
Means (1932) dalam La Porta et al. (1999). La Porta et al. (1999) menyebutkan bahwa struktur kepemilikan tersebar umumnya terjadi di negara-negara common law dengan perlindungan hak investor yang kuat seperti Amerika Serikat dan Inggris. Dengan adanya konflik seperti ini pemilik (prinsipal) dituntut untuk melakukan sesuatu agar kebijakan yang diambil oleh pihak manajemen bisa selaras dengan tujuan yang diinginkan oleh pemilik.

Konflik keagenan tipe 2 terjadi pada perusahaan dengan struktur kepemilikan yang terkonsentrasi. Konflik yang terjadi yaitu antara pemegang saham pengendali dan pemegang saham non pengendali. Konflik ini terjadi ketika pemegang saham pengendali yang memiliki hak untuk mengendalikan perusahaan membuat suatu kebijakan yang mengabaikan kepentingan pemegang saham non pengendali. Struktur kepemilikan terkonsentrasi mayoritas terjadi di negara Asia termasuk Indonesia yang merupakan civil law dengan perlindungan hak investor yang cenderung lemah. Penelitian yang dilakukan oleh Claessens et al. (2002) mengenai struktur kepemilikan perusahaan di sembilan negara Asia menunjukkan bahwa perusahanperusahaan publik di Asia mempunyai struktur kepemilikan terkonsentrasi dalam kepemilikan keluarga.

Berdasarkan uraian mengenai konflik keagenan tipe 1, perusahaan keluarga memiliki konflik keagenan yang cukup rendah. Pengawasan menjadi lebih mudah dilakukan karena keluarga memiliki hak untuk mengontrol perusahaan dan manajemen. Apalagi banyak anggota keluarga yang terlibat didalam manajemen. Jika seperti itu, perusahaan keluarga lebih efisien dibanding non keluarga karena manajemen rata-rata didominasi oleh anggota keluarga sehingga biaya keagenan menjadi lebih rendah (Atmaja et al., 2009). Namun, hal ini akan menimbulkan masalah lainnya yang mengarah pada konflik keagenan tipe 2 yaitu benturan kepentingan antara keluarga dan pemegang saham minoritas. Keluarga akan dengan mudah mengendalikan manajemen untuk mendapatkan manfaat privat apalagi dengan kehadiran keluarga dalam manajemen. Situasi seperti ini akan mengarah pada ekspropriasi. Menurut Claessens et al. (2000) ekspropriasi adalah tindakan penggunaan hak kontrol yang dimiliki pemegang saham pengendali untuk mendapatkan manfaat pribadi dengan distribusi kekayaan dari pihak lain.

\subsection{Keluarga Sebagai Pemilik Ultimat}

La porta et al. (1999) mengkaji struktur kepemilikan 691 perusahaan publik di 27 negara dari benua Asia, Eropa, Amerika dan Australia. La porta et al., (1999) merupakan peneliti pertama yang menggunakan konsep kepemilikan ultimat untuk mengidentifikasi struktur kepemilikan. Penelitian ini berhasil membuktikan bahwa kepemilikan perusahaan publik hampir di semua negara adalah terkonsentrasi kecuali di Amerika Serikat, Jepang dan Inggris. La Porta et al. (1999) menemukan bahwa perusahaan publik di Asia Tenggara dikendalikan oleh pemegang saham ultimat. Kepemilikan ultimat adalah kepemilikan langsung dan tidak langsung terhadap perusahaan. Kepemilikan langsung adalah presentasi saham yang dimiliki atas nama sendiri sementara kepemilikan tidak langsung adalah kepemilikan terhadap suatu perusahaan melalui perusahaan lain (Siregar, 2011). Kepemilikan 
ultimat dapat menelusuri pemegang saham pengendali, hak aliran kas dan hak kontrol.

Pemilik ultimat bisa berasal dari pemerintah, institusi, asing dan keluarga. Kepemilikan keluarga merupakan kepemilikan mayoritas yang ada pada perusahaan di Indonesia. Penelitian yang dilakukan oleh Claessens et al. (2002) mengenai struktur kepemilikan perusahaan di sembilan negara Asia menunjukkan bahwa perusahan-perusahaan publik di Asia mempunyai struktur kepemilikan terkonsentrasi dalam kepemilikan keluarga.

Morck dan Yeung (2004) mendefinisikan perusahaan keluarga adalah perusahaan yang dijalankan oleh penerus dari orang yang sebelumnya bertanggungjawab terhadap perusahaan atau oleh keluarga yang dalam proses untuk menyerahkan kendali perusahaan kepada penerusnya. Jadi keluarga merupakan pemilik sekaligus pengendali perusahaan. Keluarga sebagai pemilik ultimat memiliki dampak yang cukup besar bagi perusahaan. Sebagai pemilik ultimat, keluarga dapat leluasa mengontrol perusahaan dengan hak kontrol yang dimiliki. Perusahaan keluarga terkadang menempatkan anggota keluarganya sehingga keselarasan tujuan antara pemilik dan manajer lebih mudah diwujudkan (La Porta et al, 2002). Oleh karena itu, keluarga bisa mengangkat siapa pun untuk menempati posisi manajer dan juga memberhentikan manajer. Sudah menjadi tradisi bahwa penerus perusahaan merupakan generasi keluarga selanjutnya. Hal ini menjadikan perusahaan keluarga memiliki keunikan dibanding perusahaan non keluarga. Perusahaan keluarga biasanya memiliki orientasi untuk perencanaan jangka panjang karena berkaitan langsung dengan kehidupan keluarga sehingga pemilik perusahaan termotivasi untuk memberikan yang terbaik bagi perusahaan secara berkelanjutan. Pengambilan keputusan akan menjadi lebih fleksibel dan tidak sekaku perusahaan non keluarga karena orang-orang yang berada dalam manajemen kebanyakan merupakan berasal dari keluarga sehingga sudah terjalin hubungan yang akrab. Selain itu, pengawasan akan lebih efisien dilakukan karena manajemen berasal dari keluarga. Namun, keterlibatan keluarga dalam manajemen rentan dengan benturan kepentingan antara keluarga dan pemegang saham non pengendali. Benturan kepentingan terjadi ketika manajemen yang dikendalikan keluarga melakukan tindakan yang hanya memperkaya pemilik perusahaan saja.

Keluarga sebagai pemilik ultimat memainkan peran penting dalam penentuan kebijakan perusahaan. Keluarga memiliki suara yang cukup kuat untuk mempengaruhi kebijakan perusahaan. Salah satu kebijakan penting dalam perusahaan adalah kebijakan dividen. Kebijakan dividen merupakan kebijakan untuk membagikan laba yang diperoleh dalam bentuk dividen atau menyimpan laba untuk membiayai aktivitas perusahaan. Dividen ditentukan dalam rapat umum pemegang saham (RUPS). Rapat umum pemegang saham ditentukan oleh pemegang saham pengendali tanpa memperhatikan suara pemegang saham non pengendali. Jadi merupakan hal yang mungkin bagi keluarga untuk menentukan kebijakan sesuai dengan kepentingan keluarga.

\section{Pengembangan Hipotesis}

Perusahaan keluarga sering melibatkan anggota keluarganya dalam manajemen perusahaan sehingga keselarasan tujuan lebih mudah diwujudkan 
(La Porta et al., 2002). Begitu juga dalam pengambilan keputusan, kontrol keluarga sebagai pemegang saham pengendali akan mempengaruhi keputusan yang dibuat manajemen seperti kebijakan dividen yang ditentukan dalam RUPS. Keluarga sebagai pemegang saham pengendali memiliki suara yang cukup kuat dalam RUPS tanpa memperhatikan suara pemegang saham minoritas. Free cash flow yang dimiliki perusahaan dapat menimbulkan konflik kepentingan.

Manajemen dibawah kendali keluarga bisa membuat kebijakan yang merugikan pemegang saham minoritas dengan tidak membagikan free cash flow tersebut dalam bentuk dividen. Jika free cash flow tidak dibagikan maka besar kesempatan pemegang saham pengendali memanfaatkannya untuk halhal yang menguntungkan kepentingan pribadi saja. Pengurangan dividen dapat menunjukkan bahwa terjadi ekspropriasi dalam perusahaan karena aliran kas yang tersedia di perusahaan digunakan hanya untuk kepentingan pemegang saham pengendali (Siregar, 2007). Kehadiran komisaris independen seharusnya bisa meminimalisir tindakan tersebut. Namun proporsi komisaris independen dalam perusahaan keluarga cukup rendah (Atmaja et al., 2009).

Sementara itu, pemilik perusahaan non keluarga di Indonesia banyak dipegang oleh pemegang saham mayoritas yang dimiliki oleh pemerintah, institusional, dan asing. Meskipun begitu, manajemen perusahaan non keluarga biasanya berasal dari kalangan profesional yang tidak memiliki hubungan keluarga dengan pemilik. Proporsi komisaris independen pada perusahaan non keluarga lebih tinggi sehingga pengawasan terhadap manajemen lebih efektif. Jadi hak pemegang saham bisa terwakili oleh komisaris independen.

Perusahaan keluarga cenderung bergantung pada pendanaan eksternal yaitu hutang untuk mendanai kegiatan perusahaan. Keluarga tidak ingin mengurangi kontrol yang telah dimilikinya oleh karena itu perusahaan keluarga lebih memilih hutang daripada menerbitkan saham baru yang menyebabkan beralihnya kepemilikan saham. Semakin tinggi kontrol keluarga maka semakin tinggi hutang yang dimiliki (Wijayanti, 2014). Hal ini sejalan dengan penelitian Atmaja (2009) yang menyatakan bahwa perusahaan keluarga memiliki proporsi dewan komisaris independen yang rendah dan memiliki hutang yang tinggi dibanding perusahaan non keluarga. Jika perusahaan memiliki hutang yang tinggi maka proporsi laba yang dibagikan dalam bentuk dividen akan semakin kecil.

Berdasarkan uraian di atas maka hipotesis dalam penelitian ini adalah sebagai berikut :

H1 : Terdapat perbedaan signifikan pembayaran dividen antara perusahaan keluarga dan perusahaan non keluarga.

\section{METODE PENELITIAN}

\section{Sampel dan Data Penelitian}

Populasi pada penelitian ini adalah seluruh perusahaan yang terdaftar pada Bursa Efek Indonesia dari tahun 2009-2012. Pemilihan sampel dilakukan dengan menggunakan purposive sampling. Menurut Jogiyanto (2010) purposive sampling merupakan pengambilan sampel dari populasi 
berdasarkan suatu kriteria tertentu. Kriteria sampel yang digunakan dalam penelitian ini adalah :

1. Perusahaan masuk kategori industri manufaktur yang terdaftar di BEI dari tahun 2009-2012.

2. Perusahaan yang bisa ditelusuri secara kepemilikan ultimat.

3. Perusahaan yang memiliki saldo laba positif.

4. Perusahaan yang mempublikasikan laporan keuangan secara lengkap dalam periode penelitian.

Penelitian ini menggunakan data sekunder perusahaan-perusahaan yang terdaftar di Bursa Efek Indonesia (BEI) dari tahun 2009 sampai dengan 2012. Data yang digunakan dalam penelitian ini diperoleh dari laporan keuangan yang dipublikasikan di situs Bursa Efek Indonesia (www.idx.co.id). Data mengenai struktur kepemilikan diperoleh dari Pusat Data Bisnis Indonesia melalui penelitian Sanjaya (2010).

\section{Definisi dan Operasionalisasi Variabel}

Variabel dalam penelitian ini adalah dividen. Dividen diproksikan dengan dividend payout ratio.

$$
\text { DPR }=\frac{\text { Dividend } \text { Per Share }}{\text { Earnings Per Share }}
$$

\section{Model Empiris}

Pengujian hipotesis dilakukan menggunakan uji beda mann-whitney pada program SPSS. Model empiris penelitian ini adalah sebagai berikut :

$\mathbf{Y}=\mathbf{X}_{\mathbf{1}} \neq \mathbf{X}_{\mathbf{2}}$

$\mathrm{Y}=$ Dividen

$\mathrm{X}_{1}=$ Perusahaan Keluarga

$\mathrm{X}_{2}=$ Perusahaan Non Keluarga

\section{ANALISIS DATA DAN PEMBAHASAN}

\section{Deskripsi Umum Sampel}

Objek penelitian yang digunakan dalam penelitian ini adalah perusahaan manufaktur yang terdaftar di Bursa Efek Indonesia tahun 2009-2012. Pengambilan sampel dilakukan dengan cara purposive sampling. Rincian penarikan sampel dapat dilihat dalam tabel 4.1.

\section{Tabel 4.1}

Proses Pemilihan Sampel

\begin{tabular}{|l|c|}
\hline \multicolumn{1}{|c|}{ Kriteria } & $\begin{array}{c}\text { Tahun } \\
\text { Perusahaan }\end{array}$ \\
\hline $\begin{array}{l}\text { Jumlah tahun perusahaan manufaktur yang terdaftar di BEI } \\
\text { tahun 2009-2012 }\end{array}$ & 546 \\
\hline Perusahaan yang mengalami rugi dalam periode penelitian & $(75)$ \\
\hline Data tidak lengkap & $(36)$ \\
\hline Tidak bisa ditelusuri secara ultimat & $(35)$ \\
\hline Total sampel tahun perusahaan yang digunakan & 400 \\
\hline
\end{tabular}




\section{Statistik Deskriptif}

Statistik deskriptif dilihat dari nilai mean, standar deviasi, maksimum, dan minimum. Hasil pengujian statistik deskriptif disajikan dalam tabel berikut.

Tabel 4.2

Hasil Statistik deskriptif

Descriptive Statistics

\begin{tabular}{|c|c|c|c|c|c|}
\hline & $\mathrm{N}$ & Minimum & $\underset{\mathrm{m}}{\operatorname{Maximu}}$ & Mean & $\begin{array}{l}\text { Std. } \\
\text { Deviation }\end{array}$ \\
\hline DPR & 400 & .0000 & 1.5150 & .240357 & .3127405 \\
\hline$\underset{\text { (listwise) }}{\text { Valid }} \mathrm{N}$ & 400 & & & & \\
\hline
\end{tabular}

Tabel 4.3 menunjukkan bahwa rata-rata dividend payout ratio perusahaan baik perusahaan keluarga dan perusahaan non keluarga yaitu 0,240357. Nilai minimum yaitu 0 yang artinya tidak membayar dividen sama sekali dan nilai maksimumnya 1.5150

\section{Uji Normalitas}

Uji normalitas dilakukan untuk mengetahui apakah data sudah terdistribusi dengan normal atau belum. Pengujian ini menggunakan kolmogorov-smirnov. Hasil pengujian dpat dilihat dari tabel berikut ini.

Tabel 4.3

Hasil Uji Normalitas

One-Sample Kolmogorov-Smirnov Test

\begin{tabular}{|c|c|c|}
\hline & & DPR \\
\hline \multicolumn{2}{|l|}{$\mathrm{N}$} & 400 \\
\hline \multirow{2}{*}{$\begin{array}{l}\text { Normal } \\
\quad \text { Parameters }^{\mathrm{a}}\end{array}$} & Mean & .245355 \\
\hline & Std. Deviation & .3347595 \\
\hline \multirow{3}{*}{$\begin{array}{c}\text { Most Extreme } \\
\text { Differences }\end{array}$} & Absolute & .232 \\
\hline & Positive & .196 \\
\hline & Negative & -.232 \\
\hline \multicolumn{2}{|c|}{ Kolmogorov-Smirnov Z } & 4.636 \\
\hline \multicolumn{2}{|c|}{ Asymp. Sig. (2-tailed) } & .000 \\
\hline
\end{tabular}

Untuk menentukan apakah data terdistribusi dengan normal atau tidak dapat dilihat dari signifikansinya. Jika signifikansi di bawah 0,05 berarti data tidak terdistribusi dengan normal, dan jika di atas 0,05 berarti data terdistribusi dengan normal. Dari tabel 4.4 dapat dilihat signifikansi $0,000<$ 0,05 . Jadi data tidak terdistribusi dengan normal dan akan menggunakan pengujian non parametrik untuk pengujian selanjutnya 


\section{Uji Mann-Whitney}

Uji ini dilakukan untuk mengetahui ada tidaknya perbedaan yang signifikan antara dua sampel yang independen. Hasil uji disajikan dalam tabel berikut ini.

Tabel 4.4

\section{Analisis Data}

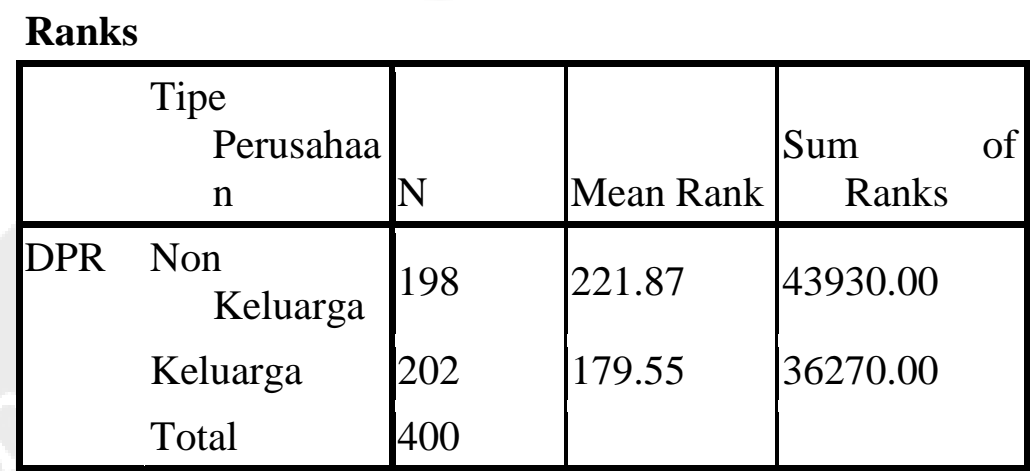

Test Statistics ${ }^{\mathrm{a}}$

\begin{tabular}{|l|l|}
\hline & DPR \\
\hline Mann-Whitney U & 15767.000 \\
Wilcoxon W & 36270.000 \\
Z & -3.812 \\
Asymp. Sig. (2-tailed) & .000 \\
\hline
\end{tabular}

a. Grouping Variable: Tipe Perusahaan

Berdasarkan tabel 4.5 dapat dilihat bahwa asymp. Sig. (2-tailed) adalah 0,000 . Penelitian ini menggunakan alpha sebesar 0,005 sementara nilai $\mathrm{p}<$ 0,005 . Oleh karena itu, terdapat perbedaan yang signifikan antara perusahaan keluarga dan perusahaan non keluarga dalam pembayaran dividen. Perusahaan non keluarga memiliki mean rank yang lebih tinggi yaitu sebesar 221,87 dan sum of ranks 43930 dibanding perusahaan keluarga yaitu 179,55 dengan sum of ranks 36270.

\section{Analisis Perbedaan Pembayaran Dividen pada Perusahaan Keluarga} dan Non Keluarga

Pengujian empiris diperlukan untuk mendapatkan bukti yang mendukung hipotesis. Analisis data yang digunakan untuk menguji hipotesis adalah uji beda rata-rata. Sebelum melakukan uji beda rata-rata, penelitian ini melakukan uji normalitas dahulu untuk melihat apakah data telah terdistribusi dengan normal. Hasil uji normalitas menggunakan kolmogorov smirnov menunjukkan bahwa data tidak terdistribusi dengan normal. Oleh karena itu dilakukan pengujian non parametrik menggunakan uji Mann-Whitney untuk mengetahui ada tidaknya perbedaan diantara kedua sampel. Dari pengujian didapat asymp. Sig. (2-tailed) bernilai $0,000<0,005$ yang menunjukkan 
bahwa terdapat perbedaan yang signifikan antara perusahaan keluarga dan non keluarga.

Kepemilikan keluarga merupakan kepemilikan yang sering ditemukan pada perusahaan publik di Indonesia berdasarkan penelitian Claessens et al, (2002). Kepemilikan saham pada perusahaan keluarga mayoritas dimiliki oleh pihak-pihak yang berafiliasi dengan keluarga sehingga keluarga menjadi pemegang saham pengendali dalam perusahaan.

Penelitian ini menggunakan konsep kepemilikan ultimat untuk menentukan apakah perusahaan tersebut merupakan perusahaan keluarga atau non keluarga. Berbeda dengan perusahaan keluarga, perusahaan non keluarga dalam hal kepemilikan saham mayoritas bisa dimiliki oleh institusi, asing, pemerintah atau masyarakat umum. Berikut ini merupakan komparasi pembayaran dividen pada perusahaan keluarga dan perusahaan non keluarga.

Tabel 4.5

Komparasi Pembayaran Dividen

\begin{tabular}{|l|l|l|}
\hline Kategori & Perusahaan Keluarga & Perusahaan Non Keluarga \\
\hline Membayar dividen & 98 & 131 \\
\hline Tidak Membayar dividen & 104 & 67 \\
\hline Jumlah & 202 & 198 \\
\hline
\end{tabular}

Selain pembagian dividen yang rendah, perusahaan keluarga juga lebih banyak yang jarang membayar dividen jika dibandingkan dengan perusahaan non keluarga. Dari 202 pengamatan perusahaan keluarga, 104 diantaranya tidak membayar dividen dalam rentang tahun 2009- 2012. Sementara 198 pengamatan perusahaan non keluarga hanya 67 yang tidak membayar dividen. Ada beberapa kemungkinan yang menyebabkan perusahaan keluarga membayar dividen yang lebih rendah dibanding perusahaan non keluarga. Pertama, jika ditinjau dari konflik keagenan tipe 2 keluarga sebagai pemegang saham pengendali bisa melakukan ekspropriasi dengan menggunakan hak kontrol yang dimiliki untuk mengendalikan perusahaan untuk memperoleh manfaat pribadi. Ekspropriasi akan semakin mudah dilakukan ketika pihak manajemen ditempati oleh anggota keluarga. Siregar (2007) menyebutkan bahwa dividen dapat menjadi sarana yang ideal untuk membatasi kemungkinan ekspropriasi oleh pemegang saham pengendali karean dividen menunjukkan pembayaran terhadap pemegang saham secara pro-rata. Namun, perusahaan keluarga belum menjadikan dividen untuk mengatasi konflik keagenan yang mengarah kepada eksrpopriasi.

Kedua, La porta et al. (1999) mengindikasikan bahwa keluarga biasanya terlibat dalam manajemen perusahaan. Sisi positif keterlibatan keluarga dalam manajemen yaitu tercipta keselarasan tujuan antara keluarga dan manajemen. Pemilik lebih mudah mengawasi manajemen karena mayoritas pihak manajemen berasal dari keluarga. Sementara itu, sisi negatifnya yaitu keluarga menempatkan anggota keluarga yang kurang berkompeten dalam menjalankan perusahaan yang mengakibatkan menurunnya kinerja perusahaan. Jika kinerja perusahaan menurun maka laba yang dihasilkan juga menurun yang berdampak pada tidak dibagikannya dividen. 
Ketiga, perusahaan keluarga lebih banyak membiayai kegiatan perusahaan melalui pendanaan eksternal yaitu hutang. Keluarga tidak ingin kehilangan kontrol yang dimiliki sehingga lebih memilih hutang daripada menerbitkan saham baru yang berakibat pada meluasnya kepemilikan saham publik. Perjanjian hutang menyebabkan perusahaan memiliki tanggungan untuk membayar hutang beserta bunga kepada kreditor. Laba yang diperoleh perusahaan akan digunakan untuk membayar hutang terlebih dahulu, setelah itu sisa laba akan ditahan yang berakibat pada pembayaran dividen yang rendah atau tidak dibagikannya dividen sama sekali.

Penelitian ini sejalan dengan penelitian yang dilakukan Wei et al. (2011) yaitu perusahaan keluarga memiliki dividend payout ratio yang rendah dibanding perusahaan non keluarga sehingga membagikan dividen yang lebih rendah. Penelitian ini juga mendukung penelitian yang dilakukan oleh Wijayanti (2014) bahwa perusahaan yang dikontrol keluarga di Indonesia memiliki pengaruh negatif signifikan terhadap kebijakan dividen. Perusahan yang dikontrol keluarga membagikan dividen lebih kecil dibanding perusahaan non keluarga. Perlindungan hukum investor di Indonesia juga tergolong masih lemah yang mendukung pengaruh negatif kontrol keluarga terhadap pemegang saham minoritas.

\section{PENUTUP}

\section{Kesimpulan}

Berdasarkan hasil pengujian dan analisis yang dilakukan dalam penelitian ini maka dapat disimpulkan bahwa terdapat perbedaan pembayaran dividen yang signifikan antara perusahaan keluarga dan perusahaan non keluarga. Perusahaan keluarga membayar dividen lebih rendah dibanding perusahaan non keluarga.

\section{Keterbatasan penelitian dan Saran}

Penelitian ini memiliki beberapa keterbatasan yaitu :

1. Periode penelitian yang digunakan terlalu pendek yaitu hanya dari tahun 2009 - 2012 saja. Periode penelitian selanjutnya diharapkan lebih lama agar didapatkan hasil yang lebih mencerminkan keadaan yang sesungguhnya.

2. Objek penelitian hanya terbatas pada perusahaan manufaktur sehingga belum bisa mewakili perusahaan yang ada di Bursa Efek Indonesia. Penelitian selanjutnya diharapkan bisa meneliti selain di industri manufaktur.

3. Penelitian ini tidak mempertimbangkan saldo laba negatif perusahaan. 


\section{DAFTAR PUSTAKA}

Brigham, E.F., dan Houston, J.F. 2001. Manajemen Keuangan. Erlangga, Jakarta.

Claessens, S., S. Djankov, dan L. H. P. Lang, 2000. The Separation of Ownership and Control in East Asian corporations, Journal of Financial Economics, 58 : 81-112.

Claessens, S., Djankov, S., Fan, J.P. H., dan Lang, L. H. P. 2002. Disentangling the Incentive and Entrenchment Effects of Large Shareholders. The Journal of Finance, LVII :2741-2771.

Easterbrook, F.H. 1984. Two Agency-cost Explanations of Dividends. American Economic Review, 74 : 650-659.

Eisenhardt, Kathleen. 1989. Agency Theory : As Assesment and Review. The Academy of Management Review, 14 : 57-74.

Indrastiti. 2013. BEI Bakal Atur Emiten Tak Bagi Dividen. http://investasi.kontan.co.id/news/bei-bakal-atur-emiten-tak-bagi-dividen. Jumat, 01 Februari 2013

Jensen M. C., dan Meckling W.H. 1976. Theory of The Firm : Managerial Behaviour, Agency, and Ownership Structure. Journal of Financial Economics, 3 : 305-360.

Jogiyanto, H.M. 2010. Metodologi Penelitian Bisnis: Salah Kaprah dan Pengalaman-Pengalaman (Edisi 6). BPFE : Yogyakarta.

La Porta, R., Lopez-de-Silanes, dan F., Shleifer, A. 1999. Corporate Ownership Around the World. Journal of Finance, LIV : 471-517.

La Porta, R., Lopez-de-Silanes, F., Shleifer, A.,danVishny, R.W. 2000. Agency Problem and Dividend Policies Aroud the World. Journal of Finance, 55 :133. 
Mahadwartha, Putu Anom. 2002. The Association of Managerial Ownership With Dividend Policy and Leverage Policy : Indonesian Firm. National Seminar Surviving Strategies to Cope with The Future.

Morck, Randall \& Yeung, Bernard, 2004. Special Issues Relating to Corporate Governance and Family Control. Policy Research Working Paper Series 3406. The World Bank.

Pindado, J.,Requejo I., dan Torre C. 2012. Do Family Firms Use Dividend Policy as a Governance Mechanism? Evidence from the Euro Zone. Corporate Governance: An International Review, 20(5) :413-431.

Setia-Atmaja, L., Tanewski, G.A., Skully, M. 2009. The Role of Dividends, Debt and Board Structure in the Governance of Family Controlled Firms. Journal of Business Finance \& Accounting, 36 : 863-898.

Siregar, Baldric. 2008. Pengaruh Pemisahan Hak Aliran Kas dan Hak Kontrol Terhadap Dividen. Jurnal Riset Akuntansi Indonesia, 11(2): 158-185.

Siregar, Baldric. 2011. Kebijakan Dividen pada Perusahaan yang Dikendalikan oleh Pemgang Saham Pengendali. Jurnal Akuntansi dan Manajemen, 22 : 257-275.

Sanjaya. 2010. Entrenchment and Alignment Effect on Earnings Management. The Indonesian Journal of Accounting Research, 13(2): 247-264.

Wei, Z., Wu, S., Li, C., Chen, W. 2011. Family Control, Institutional Environment and Cash Dividend Policy: Evidence From China. China Journal of Accounting Research, 4 : 29-46.

Wijayanti, Lulud. 2014. Pengaruh Kontrol Keluarga dan Komisaris Independen Terhadap Kebijakan Dividen Dan Struktur Modal Pada Perusahaan Yang Terdaftar Di BEI. Jurnal Bisnis Indonesia, 1:81-89. 